Chapter 22

\title{
Integrating Herbicides in a High-Residue Cover Crop Setting
}

\author{
Andrew J. Price and Jessica A. Kelton \\ Additional information is available at the end of the chapter \\ http://dx.doi.org/10.5772/56142
}

\section{Introduction}

Sustainable agriculture requires the use of multiple, integrated weed management practices to ensure long-term viability. A number of cultural, mechanical, and chemical weed control options can be utilized in a production system to reduce weed interference and safeguard crop yield. The dependence on one single weed control strategy may result in short-term success; however, long-term use can lead to multiple setbacks including poor soil health, reduced crop production, and increasing herbicide resistance. In turn, employing multiple weed control tactics simultaneously may prove difficult without previous knowledge as to how best to implement an integrated weed management system. To that end, this chapter is dedicated to illustrating successful herbicide use in conjunction with cover crops and their residues, practices proven not only to suppress weed germination and growth, but also to reduce soil erosion and water runoff and build soil organic matter and thus subseqent productivity.

Use of cover crops, particularly those producing high amounts of biomass (greater than 4,500 $\mathrm{kg} \mathrm{ha}^{-1}$ ), can provide numerous benefits for a cropping system [1]. However, care must be taken when choosing herbicides to apply to these cover crops both prior to and after primary crop planting. This chapter provides an overview of effective herbicide choices for use prior to and within cover crop as well as efficient application methods for use after planting the primary crop(s). We also discuss herbicide interception by cover crop residue and means to control reduced efficacy due to interception. It is hoped that this summary will aid in the adoption of sustainable farming practices to ensure successful agricultural productivity for future generations. 


\section{Conservation agriculture}

As demands are placed on agriculture to produce increasing yields for a growing global population, the need to implement systems with high productivity and sound environmental standards is key to ensuring agricultural sustainability for future generations. To this end, conservation agriculture is a systems-based approach for food, feed, and fiber production that utilizes a number of practices aimed at maintaining yields while limiting energy and chemical inputs, minimizing soil degradation and erosion, and reducing long-term, detrimental impacts to the environment [2]. Conservation agriculture is comprised of many different management practices, particularly cultural techniques such as crop rotation, planting date, and seeding rate, that can reduce dependence on chemical inputs for successful yield production. Moreover, limited tillage practices, or conservation-tillage, is essential to conservation agriculture systems to ensure soil quality, reduce runoff, and lessen energy consumption on agricultural lands.

\subsection{Conservation tillage}

Conservation-tillage, or reduced-tillage, has been proven to provide multiple benefits in agricultural settings. In addition to erosion and runoff control, soil health improvement, and reduced energy demands, reduced-tillage practices can produce crops yields similar to that of conventional systems [3-5]. The use of reduced-tillage, however, can alter weed communities. Seed production by annual weed species remains, in most part, on the soil surface where it is subject to increased decomposition and predation. With reduced competition and minimized soil disruption, perennial weed species can become established and dominate the weed community in conservation-tillage [6]. To aid in the control of both annual and perennial weeds, the use of cover crops for ground cover can reduce herbicide requirements in conservation-tillage settings.

\subsection{Cover crops}

A number of cereal and legume cover crops are utilized in various crop productions for several purposes. Currently, a large portion of cover crops are planted as a green manure which are turned under prior to sowing the primary crop $[7,8]$. In reduced-tillage, however, cover crops are grown as a ground cover and remain on the soil surface after cover crop termination. In addition to further reducing soil erosion, increasing soil organic matter, and improving water infiltration, cover crops can provide a level of weed suppression both prior to and during the primary growing season [9]. When compared to fallow conservation-tillage systems, cover crops offer increased weed control through direct resource competition while actively growing as well as through shading and/or allelopathy after termination. Covers grown to produce high levels of biomass, in particular, can increase shading of germinating weed species and provide greater ground cover for an extended period during the growing season. When employing cover crops, however, knowledge concerning herbicide use both during cover crop production and primary crop growth is essential. 


\subsection{Herbicide use}

\subsubsection{Cover crop establishment and termination}

To produce substantial cover crop biomass, it is imperative to adequately manage cover crop production. Besides using correct seeding rates, early planting dates, and sufficient fertilizer applications, it is important to be aware of herbicide applications made prior to cover crop establishment. Often times, postemergent (POST) herbicides applied late season or postharvest can have residual carryover than may be detrimental to cover crops. Rotation restrictions listed on herbicide labels should be referred to when planning POST applications and cover crop species.

To manage cover crops before cash crop planting, herbicides are typically utilized for cover crop termination. Most often, these herbicides, such as glyphosate and glufosinate, are nonselective with little to no carryover risk. However, consideration should be given to in-season chemical weed control regimes in order to limit repeated applications of a single herbicide mode of action. Moreover, care should be taken to avoid reduced herbicide rates applied for cover termination to reduce the risk of herbicide resistance [10]. Recent research has focused on mechanical termination with a roller or crimper which may reduce or eliminate the need of these herbicides for cover crop termination [11].

\subsubsection{Cash crop establishment and management}

Although use of in-season herbicides can be substantially reduced when using high-residue cover crops, some chemical applications are generally required to achieve the most effective weed suppression and minimize crop loss due to weed competition. While an ideal agricultural system would require no chemical inputs for sufficient weed control, practicality dictates the use of herbicides to guarantee crop yield since no system, as of yet, exists that can successfully suppress weed populations without intensive labor or mechanical requirements. To this end, cover crops are a means to minimize, rather than eliminate, herbicide inputs in crop systems. In recognizing the fact that the majority of agricultural systems will require chemical weed control measures for optimum crop production even when utilizing cover crops, it is essential to understand how cover crops affect herbicide selection and efficacy for each crop.

Primarily, the use of reduced-tillage and cover crops eliminates the ability to utilize preplant incorporated herbicides which offer residual soil activity [11]. Furthermore, cover crop residue can impede preemergent (PRE) herbicide applications from reaching the soil surface, reducing herbicide efficacy [12]. While postemergent chemical weed control can be effective alternatives in these settings, many weed species can prove to be difficult to control if not killed early in the season. Moreover, resistance concerns essentially necessitate the use of preemergent herbicides with differing mechanisms of action to avoid selection pressure for resistant weed biotypes [13].

Along with many cultural pracitces, production of crops under reduced-tillage with cover crops requires development of specific herbicide regimes to ensure minimal chemical inputs while achieving sufficient weed control to allow for successful crop production. The following 
sections review major crops produced globally, describe research conducted in respect to reduced-tillage production, as well as list available herbicides for use when using reducedtillage and cover crops. These reviews are designed to provide information that can be beneficial for producers implementing conservation-tillage.

\section{Wheat}

Global production of wheat (Triticum aestivum L.) was estimated at approximately 217 million hectares in 2010 [14] representing the largest single crop, in area grown, and providing approximately $19 \%$ of the caloric intake of the world's diet [15]. In recent years, concerns have been noted over stagnant wheat yields due to drought and rising temperatures attributed to global warming [16]. Efforts to maintain current wheat production levels and identify potential measures to aid in increasing yield have led researchers to explore conservation practices in wheat systems. In addition to preserving high crop yields, long-term conservation systems are intended to protect environmental quality and reduce chemical and energy inputs necessary for crop production. Components of conservation systems such as reduced- or no-tillage can produce crop yields equal to or exceeding conventional tillage practices while reducing erosion, water runoff, and increasing water infiltration.

Much research has been conducted to evaluate wheat productivity in conservation-tillage practices. Reports reveal similar or increased grain yield for reduced-tillage compared to conventional tillage systems [17-19]. With little or no tillage operations, some chemical applications are required to achieve successful levels of weed control; however, with herbicide applications, weed species have been effectively controlled below levels that could reduce yield [20]. To offset the herbicide needs in conservation-tillage, evaluations of cover crops as ground cover have been conducted. Crops such as mustard (Sinapis alba L.), pea (Pisum sativum L.), and lentil (Lens culinaris Medik.) have proven to be good choices with little yield differences [21]. However, other reports show negative impacts on wheat production when implementing cover crops prior to wheat production for reasons such as increased weed competition, primarily Bromus spp., and reduced fertilizer uptake [22].

Like most crops produced in conservation-tillage, herbicide options may be limited to a degree whether utilizing a cover crop or not. With reduced-tillage, preplant incorporation of residual herbicides cannot be utilized. Moreover, when planting into cover crops, soil-applied preemergent herbicides may be less effective due to interception by crop residue. When planting wheat, preplant burndown herbicides may be necessary to control early weeds. POST herbicides are also necessary to control weeds that germinate after planting. Table 1 lists many of the herbicide options for use in conservation-tillage systems for wheat production.

\section{Maize}

Maize, or corn (Zea mays L.), is one of the most economically important grain crops worldwide with 162 million ha produced in 2010 [2]. In addition to being a staple in human and livestock 
diets in many countries, corn is also used for bioethanol production and the manufacturing of many non-food products. Consumption of corn and products derived from corn continues to increase. Given the demand, it is imperative for sustainable production systems that produce high yields while preserving long-term productivity of the land to be implemented.

Conservation-tillage practices have been researched and utilized for several decades in some regions such as the Midwest in the United States. As with many other crops, some variability has been noted for corn yield in no-tillage systems compared to conventional tillage methods. However, many reports show at least equal corn yields can be achieved when tillage practices are reduced [3]. Adequate yield potential, coupled with the reduction of on-farm expenses, have made conservation-tillage systems a good fit for corn production.

\begin{tabular}{|c|c|c|c|}
\hline \multicolumn{4}{|l|}{ Herbicide } \\
\hline Common Name & Trade Name $^{a}$ & $\begin{array}{l}\text { Application } \\
\text { Timing }\end{array}$ & Weed Species Controlled \\
\hline Carfentrazone & Aim $^{\circ}[23]$ & \multirow{5}{*}{$\begin{array}{l}\text { Preplant } \\
\text { Burndown }\end{array}$} & \multirow{5}{*}{$\begin{array}{l}\text { Non-selective control of emerged broadleaves } \\
\text { and grasses }\end{array}$} \\
\hline Glufosinate & Liberty $^{\circ}[24]$ & & \\
\hline \multirow[t]{2}{*}{ Glyphosate } & Roundup & & \\
\hline & WeatherMax"[25] & & \\
\hline Paraquat & Gramoxone $[26]$ & & \\
\hline Chlorsulfuron + Metsulfuron & Finesse $^{\circ}[27]$ & PRE or POST ${ }^{b}$ & $\begin{array}{l}\text { Bromus species, annual ryegrass (Lolium } \\
\text { multiflorum), kochia (Kochia scoparia) }\end{array}$ \\
\hline Pyrasulfotole + Bromoxynil & Huskie $^{\mathrm{TM}}[28]$ & Early POST & $\begin{array}{l}\text { Emerged broadleaf seedlings such as } \\
\text { dandelion (Taraxacum officinale); suppression } \\
\text { of established dandelion and henbit (Lamium } \\
\text { amplexicaule) }\end{array}$ \\
\hline Thifensulfuron + Tribenuron & $\begin{array}{l}\text { Harmony } \\
\text { Extra [29] }\end{array}$ & POST & $\begin{array}{l}\text { Actively growing broadleaves, wild garlic } \\
\text { (Allium vineale); suppression of Canada thistle } \\
\text { (Cirsium arvense) }\end{array}$ \\
\hline \multicolumn{4}{|l|}{ Clearfield wheat } \\
\hline Imazamox & Beyond $^{*}[30]$ & POST & $\begin{array}{l}\text { Broadleaves henbit and chickweed (Stellaria } \\
\text { media), grasses barnyardgrass (Echinochloa } \\
\text { crus-galli), jointed goatgrass (Aegilops } \\
\text { cylindrica), volunteer cereals (non-Clearfield } \\
\text { types) }\end{array}$ \\
\hline
\end{tabular}

Trade names listed are representative of available herbicides. Inclusion of particular trade names does not suggest author endorsement.

bPRE, preemergence; POST, postemergence.

Table 1. Herbicides for use in reduced-tillage wheat production. 
A major limiting factor to adopting reduced-tillage in corn production is the concern of less effective weed control. Tillage has long been used as a means for weed seed burial which reduces the number of seeds in the upper portion of the soil, the area most favorable for germination for most species. In addition to weed seed remaining in the upper layer of soil, shifts in weed species have also been noted. With the implementation of conservation-tillage, most crop systems experience a shift in weed species from annuals to perennials dominating the weed community.

Perennial weed species, largely controlled with tillage practices, can thrive on less disturbed crop land. For effective weed control, producers implementing reduced-tillage have relied on increased herbicide applications. To curb herbicide use, cover crops have been adopted in conjunction with reduced-tillage corn systems. Research has shown that utilizing a legume or grain cover crop can reduce weed density and growth while not affecting corn yield [31,32]. For corn in particular, cover crops offer a potential benefit in addition to weed suppression. Adequate nitrogen availability is essential for corn development. The use of legume cover crops, such as hairy vetch (Vicia villosa Roth), red clover (Trifolium pratense L.), or medics (Medicago spp.), may provide a portion of corn nitrogen requirements and reduce fertilizer inputs into the system [33]. Some research indicates that legume covers do not reduce fertilizer requirements but improves grain production with standard fertilizer applications [34]. Other research shows that legume covers can provide some nitrogen required for successful corn production[35,36]. Selecting the right legume cover crop for maximum nitrogen contribution with timely availability for corn uptake is key for utilizing these crops as nitrogen sources.

Use of burndown herbicides prior to corn planting is critical for early season weed control when using cover crops. A residual herbicide applied in conjunction with the herbicide used for cover crop termination can broaden weed species controlled as well as extend control into the season. A number of PRE herbicides are available that can be applied without incorporation into the soil and are effective even with plant residue on the soil surface. These herbicides and POST herbicide choices that can be successfully utilized in conservation-tillage corn with cover crops are listed in Table 2.

\begin{tabular}{|c|c|c|c|}
\hline \multicolumn{4}{|l|}{ Herbicide } \\
\hline Common Name & Trade Name ${ }^{\mathrm{a}}$ & Application Timing & Weed Species Controlled \\
\hline Glufosinate & Liberty $^{\infty}[24]$ & Preplant burndown & Emerged weed species \\
\hline \multirow[t]{2}{*}{ Glyphosate } & Roundup & & \\
\hline & WeatherMax [25] & & \\
\hline Paraquat & Gramoxone $[26]$ & & \\
\hline $2,4-D$ & Agri Star ${ }^{\circ}$ 2,4-D [37] & & \\
\hline Atrazine & Aatrex $[38]$ & $\begin{array}{l}\text { Preplant } \\
\text { or PRE }\end{array}$ & $\begin{array}{l}\text { Broadleaves such as kochia (Kochia scoparia); } \\
\text { suppression of foxtail (Setaria spp.), velvetleaf } \\
\text { (Abutilon theophrasti). Can also be applied POST }\end{array}$ \\
\hline
\end{tabular}




\begin{tabular}{|c|c|c|c|}
\hline \multicolumn{4}{|l|}{ Herbicide } \\
\hline Common Name & Trade Name $^{a}$ & Application Timing & Weed Species Controlled \\
\hline Flumioxazin & Valor [39] & & $\begin{array}{l}\text { Broadleaf species such as horseweed (Conyza } \\
\text { canadensis); suppression of grass species such as } \\
\text { panicum (Panicum spp.) and goosegrass (Eleusine } \\
\text { indica) }\end{array}$ \\
\hline Pendimethalin & Prowl $^{\infty}[40]$ & & $\begin{array}{l}\text { Germinating, small-seeded grass and broadleaf } \\
\text { species such as crabgrass (Digitaria spp.) and } \\
\text { common lambsquarters (Chenopodium alba) }\end{array}$ \\
\hline S-metolachlor & Dual Magnum " [41] & & $\begin{array}{l}\text { Grass and broadleaf species such as foxtail and } \\
\text { Amaranthus spp. }\end{array}$ \\
\hline Carfentrazone & $\operatorname{Aim}^{*}[23]$ & POST $^{c}$ & $\begin{array}{l}\text { Certain broadleaf weed control; tank mix with } \\
\text { atrazine or dicamba }\end{array}$ \\
\hline Bromoxynil & Buctril $^{\circ}[42]$ & & $\begin{array}{l}\text { Broadleaf weeds such as burcucumber (Sicyos } \\
\text { angulatus), giant ragweed (Ambrosia trifida) }\end{array}$ \\
\hline Dicamba & Banvel $^{s}[43]$ & & $\begin{array}{l}\text { Annual broadleaf species as well as certain } \\
\text { perennial species such as dock (Rumex spp.) and } \\
\text { wild onion (Allium sp.) }\end{array}$ \\
\hline Mesotrione & Callisto $^{\circ}[44]$ & POST & $\begin{array}{l}\text { Broadleaf species such as wild mustard (Sinapis } \\
\text { arvensis), nightshade (Solanum spp.), and Canada } \\
\text { thistle (Cirsium arvense) }\end{array}$ \\
\hline Tembotrione & Laudis ${ }^{\circ}[45]$ & & $\begin{array}{l}\text { Broadleaf and grass species such as common } \\
\text { chickweed, purple deadnettle (Lamium purpureum), } \\
\text { Amaranthus spp., and large crabgrass (Digitaria } \\
\text { sanguinalis) }\end{array}$ \\
\hline Ametryn & Evik $^{\circ}[46]$ & POST-directed spray & $\begin{array}{l}\text { Grass species such as Texas panicum, goosegrass, } \\
\text { and foxtail }\end{array}$ \\
\hline Linuron & Lorox $^{\circ}[47]$ & & $\begin{array}{l}\text { Broadleaf and grass species such as dog fennel, } \\
\text { common ragweed (Ambrosia artemisiifolia), } \\
\text { velvetleaf, and annual ryegrass (Lolium multiflorum) }\end{array}$ \\
\hline \multicolumn{4}{|l|}{ Clearfield Corn } \\
\hline $\begin{array}{l}\text { Imazethapyr + } \\
\text { Imazapyr }\end{array}$ & Lightning ${ }^{\circ}[48]$ & POST & $\begin{array}{l}\text { Broadleaves, grasses, and sedges such as kochia, } \\
\text { ragweed, quackgrass (Elytrigia repens), and } \\
\text { nutsedge (Cyperus spp.) }\end{array}$ \\
\hline \multicolumn{4}{|l|}{ LibertyLink Corn } \\
\hline Glufosinate & Liberty $^{\infty}$ & POST & $\begin{array}{l}\text { Broadleaf and grass species; ragweed, horseweed, } \\
\text { johnsongrass seedlings }\end{array}$ \\
\hline
\end{tabular}




\begin{tabular}{|c|c|c|c|}
\hline \multicolumn{4}{|l|}{ Herbicide } \\
\hline Common Name & Trade Name $^{a}$ & Application Timing & Weed Species Controlled \\
\hline Glyphosate & $\begin{array}{l}\text { Roundup } \\
\text { Weathermax }\end{array}$ & POST & $\begin{array}{l}\text { Nonselective control of some broadleaf and grass } \\
\text { species }\end{array}$ \\
\hline $\begin{array}{l}\text { Glyphosate + } \\
\text { s-metolachlor + } \\
\text { atrazine }\end{array}$ & Expert $^{\circ}[49]$ & PRE or POST & $\begin{array}{l}\text { Annual broadleaves and grasses; perennials such as } \\
\text { quackgrass, dandelion (Taraxacum officinale), and } \\
\text { Canada thistle }\end{array}$ \\
\hline
\end{tabular}

aTrade names listed are representative of available herbicides. Inclusion of particular trade names does not suggest author endorsement.

${ }^{b} \mathrm{PRE}$, preemergence.

'POST, postemergence

Table 2. Herbicides for use in reduced-tillage maize production.

\section{Rice}

Production of rice (Oryza sativa L.) in 2010 was near 154 million ha worldwide [2]. In many regions, rice provides nearly half or more of calories consumed by humans [50] and is the most important grain crop grown. Rice yield has steadily grown in the past several decades due to breeding and fertilizer advancements; however, it is necessary for rice yield to continue to improve in order to meet increased demands by a growing world population. Given that little land exists in rice-producing countries to expand production, it is necessary for methods to be established that can continue yield improvement without depleting future soil productivity.

Wetland, transplant rice production is the dominant and highest yielding rice system in most regions $[50,51]$. However, the water and energy requirements may limit rice production as competition for resources increases [52]. To reduce strain on environmental and economic resources and to ensure sustainable rice systems in the future, dry-seeded rice production has been implemented in some areas [53]. Dry-seeded rice production can be initiated in conjunction with conservation-tillage with fewer water demands, lower energy and labor requirements, and reduced soil erosion. Research has reported that dry-seeded rice in no-tillage can be a successful alternative to conventional systems [52].

A limiting factor to widespread adoption of dry-seeded, reduced-tillage rice, however, is reduced weed control. For rice, transitioning from wetland, conventional systems to a dry system with reduced-tillage can affect weed compositions in multiple ways. Standing water can reduce germinating weed seeds while the transplanted rice becomes established; removing this water barrier can increase weed numbers [54]. Additionally, reduced-tillage practices can result in an increase of weed seed germination due to less seed burial.

In dry-seeded rice, mulches have been suggested as a means to combat weed increases [51]. Little research has been conducted to fully understand the benefits of cover crops for weed control in rice; however, legume covers have been associated with increased rice yield and 
reduced weed biomass in upland rice [55]. Future research needs include addressing the effects of cover crops on rice production in dry-seeded rice systems.

Due to challenging weed issues in rice systems, particularly dry-seeded rice, herbicide use will continue to be necessary for effective weed suppression in both conventional and reducedtillage systems. The implementation of cover crops into these systems may lessen the herbicide requirements but will not eliminate the use of chemicals altogether. Currently there are a number of preemergent and postemergent herbicides available for use in rice production (Table 3); however, as dry-seeded, conservation-tillage rice systems increase in popularity, more herbicide options may become available.

\begin{tabular}{|c|c|c|c|}
\hline \multicolumn{4}{|l|}{ Herbicide } \\
\hline Common Name & Trade Name ${ }^{a}$ & Application Timing & Weed Species Controlled \\
\hline Clomazone & Command $^{\circ}[56]$ & $\mathrm{PRE}^{\mathrm{b}}$ & $\begin{array}{l}\text { Grass species such as barnyardgrass } \\
\text { (Echinochloa crus-galli), crabgrass (Digitaria } \\
\text { spp.), and panicum (Panicum spp.) }\end{array}$ \\
\hline Halosulfuron & Permit $^{\circ}[57]$ & & $\begin{array}{l}\text { Broadleaf species such as dayflower (Commelina } \\
\text { erecta) and kochia (Kochia scoparia). Broadleaf } \\
\text { and grass species may be controlled with a POST } \\
\text { application. }\end{array}$ \\
\hline Pendimethalin & Prowl $^{\circ}[40]$ & & $\begin{array}{l}\text { Germinating, small-seeded grass and broadleaf } \\
\text { species such as crabgrass (Digitaria spp.), foxtail, } \\
\text { and common lambsquarters (Chenopodium } \\
\text { alba) }\end{array}$ \\
\hline Quinclorac & Facet $^{*}[58]$ & & $\begin{array}{l}\text { Broadleaf and grass species such as } \\
\text { morningglory (Ipomoea spp.), and } \\
\text { barnyardgrass. Can also be applied POST }\end{array}$ \\
\hline Thiobencarb & Bolero" [59] & & $\begin{array}{l}\text { Grass and broadleaf species such as } \\
\text { barnyardgrass, dayflower (Commelina } \\
\text { communis), and eclipta (Eclipta alba) }\end{array}$ \\
\hline Acifluorfen & $\begin{array}{l}\text { Ultra } \\
\text { Blazer }[60]\end{array}$ & $\mathrm{POST}^{\mathrm{c}}$ & $\begin{array}{l}\text { Grasses and broadleaves such as foxtail (Setaria } \\
\text { spp.), panicum, and eclipta }\end{array}$ \\
\hline Bensulfuron & Londax $[61]$ & & $\begin{array}{l}\text { Broadleaf and sedge species, particularly aquatic } \\
\text { weeds such as ducksalad (Heteranthera limosa) } \\
\text { and ricefield bulrush (Scirpus mucronatus) }\end{array}$ \\
\hline Bentazon & Basagran $^{*}[62]$ & POST & $\begin{array}{l}\text { Broadleaf and sedge species such as dayflower, } \\
\text { eclipta, and yellow nutsedge (Cyperus } \\
\text { esculentus) }\end{array}$ \\
\hline Carfentrazone & Aim $^{\circ}[23]$ & & $\begin{array}{l}\text { Broadleaf species such as common cocklebur } \\
\text { (Xanthium strumarium), dayflower, and } \\
\text { Amaranthus spp. }\end{array}$ \\
\hline
\end{tabular}




\begin{tabular}{|c|c|c|c|}
\hline \multicolumn{4}{|l|}{ Herbicide } \\
\hline Common Name & Trade Name ${ }^{a}$ & Application Timing & Weed Species Controlled \\
\hline Propanil & \multicolumn{2}{|l|}{$\operatorname{Stam}^{*}[63]$} & $\begin{array}{l}\text { Grass, rush, and broadleaf species such as } \\
\text { barnyardgrass, spikerush (Eleocharis spp.), and } \\
\text { curly dock (Rumex crispus) }\end{array}$ \\
\hline Cyhalofop & Clincher $^{*}[64]$ & \multirow[t]{2}{*}{ After Flooding } & $\begin{array}{l}\text { Grass species such as barnyardgrass, broadleaf } \\
\text { signalgrass (Brachiaria platyphylla), and } \\
\text { junglerice (Echnochloa colona) }\end{array}$ \\
\hline $2,4-D$ & $\begin{array}{l}\text { Agri Star } \\
2,4-D[37]\end{array}$ & & $\begin{array}{l}\text { Annual and perennial weed species such as } \\
\text { cocklebur, morningglory, and dock }\end{array}$ \\
\hline \multicolumn{4}{|l|}{ Clearfield Rice } \\
\hline Imazamox & Beyond $^{\circ}[30]$ & \multirow[t]{3}{*}{ POST } & $\begin{array}{l}\text { Grass and broadleaf species such as } \\
\text { morningglory, barnyardgrass, and panicum }\end{array}$ \\
\hline Imazethapyr & Newpath ${ }^{\circ}[65]$ & & $\begin{array}{l}\text { Grass, sedge, and broadleaf species such as } \\
\text { barnyardgrass, morningglory, and nutsedge }\end{array}$ \\
\hline $\begin{array}{l}\text { Imazethapyr + } \\
\text { Quinclorac }\end{array}$ & Clearpath $^{\circ}$ [66] & & $\begin{array}{l}\text { Grass, sedge, and broadleaf species such as } \\
\text { junglerice, eclipta, morningglory, and nutsedge }\end{array}$ \\
\hline \multicolumn{4}{|c|}{$\begin{array}{l}\text { Trade names listed are representative of available herbicides. Inclusion of particular trade names does not suggest author } \\
\text { endorsement. }\end{array}$} \\
\hline \multicolumn{4}{|c|}{ bPRE, preemergence. } \\
\hline POST, postemer & & & \\
\hline
\end{tabular}

Table 3. Herbicides for use in reduced-tillage rice production.

\section{Soybean}

Production of soybean [Glycine $\max$ (L.) Merr.], estimated at 102 million ha in 2010 [2], meets a number of livestock and human food needs as well as industrial demands for use in products such as paints, lubricants, and biofuel. Due to its diversity of uses, the soybean is an important field crop for much of the world. In light of the value of soybeans, it is essential to establish sustainable growing practices to ensure global demand continues to be met.

Implementation of conservation practices, such as reduced-tillage, can be utilized as components of alternative management systems replacing conventional systems to provide erosion and runoff control while reducing labor and cost inputs. In the United States, in fact, approximately $80 \%$ of soybeans were produced with some form of conservation-tillage by 2006 [67]. This increase in conservation-tillage can be attributed to the environmental and economic benefits achieved with reduced-tillage as well as the commercial availability of herbicidetolerant soybeans, which have made successful chemical weed control achievable with the use of fewer herbicides. 
Early work in conservation-tillage soybean have reported equal or improved yield in soybean with reduced-tillage compared to conventional systems [68, 69]. Previous research has also examined soybean systems planted behind wheat or a cover crop such as rye with improved weed control being noted when compared to a fallow system [70] and greater yield with a cover crop than with just the previous crop's stubble [71]. The inclusion of plant residue, either from a cover crop or a previous crop, provides a level of weed control by acting as a physical barrier for germinating weed seed or through allelopathic inhibition released by some cover crop species. The weed control provided by ground cover is crucial in a no-till practice due to the loss of control from tillage reduction and the shift towards more difficult to control perennial weed species.

While cover crops and plant residue have been identified as means to reduce weed emergence when implemented in reduced-tillage practices further measures are required to keep the weed population below an acceptable level [70]. Many cultural practices, such as crop rotation, row spacing, and planting date, can be manipulated in such a way as to reduce weed populations; however, herbicide use is still necessary in many systems.

As with most field crops grown in conservation-tillage systems, soybean production with reduced-tillage has heavily relied on postemergent herbicide applications. Use of cover crops in these systems may also contribute to the tendency for fewer PRE herbicides due to interception concerns. However, the increase in herbicide-resistant weed species such as Palmer amaranth (Amaranthus palmeri S. Wats) and horsweed [Conyza canadensis (L.) Cronq.] in herbicide resistant crops, like soybean, necessitates the use of multiple herbicides to slow the development of weed resitance and safeguard the effectiveness of current herbicide options for the future. Table 4 provides a partial list of herbicides that can be utilized in reduced-tillage soybean with cover crops.

\begin{tabular}{|c|c|c|c|}
\hline \multicolumn{4}{|l|}{ Herbicide } \\
\hline Common Name & Trade Name ${ }^{a}$ & \multicolumn{2}{|c|}{ Application Timing Weed Species Controlled } \\
\hline Glufosinate & Liberty" [24] & \multirow[t]{4}{*}{ Preplant Burndown } & \multirow[t]{4}{*}{ Emerged weed species } \\
\hline Glyphosate & Roundup WeatherMax [25] & & \\
\hline Paraquat & Gramoxone $[26]$ & & \\
\hline 2,4-D & Agri Star" 2,4-D [37] & & \\
\hline \multirow[t]{4}{*}{ Clomazone } & Command $^{\circ}[56]$ & \multirow[t]{9}{*}{$\mathrm{PRE}^{\mathrm{b}}$} & Grasses and broadleaves such as crabgrass (Digitaria \\
\hline & & & spp.), panicum (Panicum spp.), velvetleaf (Abutilon \\
\hline & & & theophrasti), and Florida beggarweed (Desmodium \\
\hline & & & tortuosum) \\
\hline \multirow[t]{2}{*}{ Dimethenamid } & Outlook [72] & & Grass and broadleaf species such as foxtail (Setaria \\
\hline & & & spp.), panicum, and Amaranthus spp. \\
\hline \multirow[t]{3}{*}{ Flumioxazin } & Valor [39] & & Broadleaf species such as horseweed (Conyza \\
\hline & & & canadensis); suppression of grass species such as \\
\hline & & & panicum and goosegrass (Eleusine indica) \\
\hline
\end{tabular}




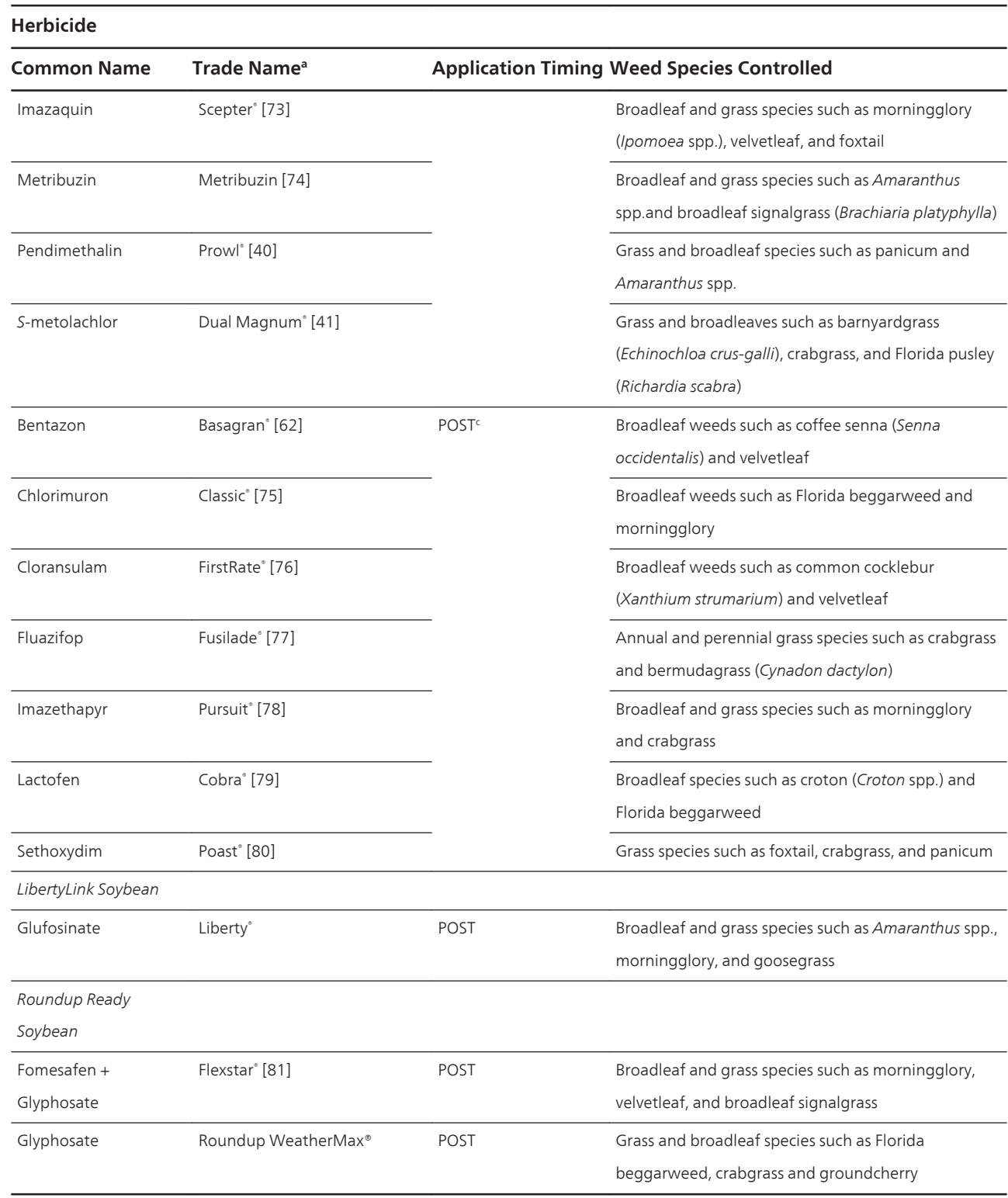

aTrade names listed are representative of available herbicides. Inclusion of particular trade names does not suggest author endorsement.

bPRE, preemergence.

'POST, postemergence.

Table 4. Herbicides for use in reduced-tillage soybean production. 


\section{Cotton}

Cotton production around the world is estimated at approximately 23 million tonnes (lint production) [2] with China, India, and the United States being the top producers [82]. Efforts to adopt sustainable cotton practices have led producers to utilize conservation-tillage systems in cotton production. Besides environmental benefits achieved with reduced-tillage, major economic advantages can be realized due to reduced time, labor, and fuel requirements when operating with less tillage. Prior to the introduction of herbicide-resistant crops, adoption of reduced-tillage was difficult due to control of weed species required multiple and costly herbicide inputs [13]. In some instances, effective herbicides were not available to control problematic weed species such as perennials that can thrive in reduced-tillage. When glyphosate-resistant cotton was made available, reduced-tillage became practical since a broad spectrum of weed species could be controlled with a single herbicide [83].

Extensive research has been carried out in conservation-tillage cotton with positive benefits seen for cotton yield [84-86]. Moreover, with herbicide-resistant cotton varieties, weed control has been as successful as conventional tillage cotton. Because of this success, conservationtillage practices have been widely adopted in areas such as the southeastern United States. This dependence on a single herbicide, however, has led to the appearance of herbicideresistant weed species and now threatens the feasibility of reduced-tillage cotton production. Currently, research efforts are focused on identifying ways to ensure the long-term viability of conservation-tillage while controlling established populations of herbicide-resistant weed species and reducing the risk of future development of resistant weeds.

Multiple weed management tactics are necessary to control weed resistance development with cover crops playing an important role in resistance management. The use of cover crops, particularly high-residue crops such as rye and black oat, can reduce herbicide inputs through shading and allelopathy. The use of high-residue crops allows for maximum shading of the soil surface during the beginning of the season while also providing a ground cover for a longer period into the growing season. Cover crops, along with multiple herbicide modes of action and rotation, have been shown to effectively control weeds in reduced-tillage cotton $[87,88]$.

A number of herbicide choices are available for use with conservation-tillage cotton (Table 5). PRE herbicides are especially important in early-season weed control to ensure management of weed species that are difficult to control later in the season. Although concerns have been raised as to whether cover crops reduce the efficacy of PRE herbicides, it has been suggested that any loss in weed control due to herbicide interception is offset by the control provided by cover crop residue [89-91].

\begin{tabular}{lll}
\hline Herbicide & \\
\hline Common Name & Trade Name $^{a}$ & Application Timing Weed Species Controlled \\
\hline Dicamba $^{\text {Flumioxazin }}$ & Banvel $^{\circ}[43]$ & Preplant Burndown Emerged weed species \\
\hline Glufosinate & Valor $^{\circ}[39]$ & \\
\hline
\end{tabular}




\begin{tabular}{|c|c|c|c|}
\hline \multicolumn{4}{|l|}{ Herbicide } \\
\hline Common Name & Trade Name ${ }^{a}$ & \multicolumn{2}{|c|}{ Application Timing Weed Species Controlled } \\
\hline \multirow[t]{2}{*}{ Glyphosate } & Roundup & & \\
\hline & WeatherMax [25] & & \\
\hline Paraquat & Gramoxone $[26]$ & & \\
\hline Clomazone & Command $^{\circ}[56]$ & Preplant or PRE ${ }^{\mathrm{b}}$ & $\begin{array}{l}\text { Grasses and broadleaves such as crabgrass } \\
\text { (Digitaria spp.), panicum (Panicumspp.), } \\
\text { velvetleaf (Abutilon theophrasti), and Florida } \\
\text { beggarweed (Desmodium tortuosum) }\end{array}$ \\
\hline Fluometuron & Cotoran $^{\circ}[92]$ & & $\begin{array}{l}\text { Grasses and broadleaves such as signalgrass } \\
\text { (Brachiaria sp.), horseweed (Conyza } \\
\text { canadensis) and sicklepod (Senna obtusifolia) }\end{array}$ \\
\hline Pendimethalin & $\operatorname{Prow}^{\circ}[40]$ & & $\begin{array}{l}\text { Grass and broadleaf species such as foxtail } \\
\text { (Setaria spp.), panicum, and Amaranthus spp. }\end{array}$ \\
\hline Prometryn & Caparol $^{\circ}[93]$ & & $\begin{array}{l}\text { Annual grass and broadleaves such as } \\
\text { groundcherry (Physalis sp.), Florida pusley } \\
\text { (Richardia scabra), and panicum }\end{array}$ \\
\hline S-metolachlor & Dual Magnum $[41]$ & & $\begin{array}{l}\text { Grass and broadleaves such as barnyardgrass } \\
\text { (Echinochloa crus-galli), crabgrass, and Florida } \\
\text { pusley }\end{array}$ \\
\hline Clethodim & Select $^{\circ}[94]$ & POST $^{c}$ & $\begin{array}{l}\text { Grass species such as crabgrass, panicum, and } \\
\text { foxtail }\end{array}$ \\
\hline \multicolumn{4}{|l|}{ Herbicide } \\
\hline Common Name & Trade Name & Application Timing & Weed Species Controlled \\
\hline Quizalofop & Assure $[95]$ & & $\begin{array}{l}\text { Annual and perennial grasses such as foxtail, } \\
\text { goosegrass (Eleusine indica), and } \\
\text { bermudagrass (Cynodon dactylon) }\end{array}$ \\
\hline Sethoxydim & Poast $^{\circ}[80]$ & POST & $\begin{array}{l}\text { Grass species such as foxtail, crabgrass, and } \\
\text { panicum }\end{array}$ \\
\hline Trifloxysulfuron & Envoke $[96]$ & & $\begin{array}{l}\text { Broadleaf and grass species such as coffee } \\
\text { senna (Senna occidentalis), barnyardgrass, } \\
\text { and Florida beggarweed }\end{array}$ \\
\hline Diuron & Direx $^{\circ}[97]$ & POST-directed spray & $\begin{array}{l}\text { Broadleaf and grass species such as sicklepod, } \\
\text { velvetleaf, and crabgrass }\end{array}$ \\
\hline Linuron & Linex $^{*}[98]$ & & $\begin{array}{l}\text { Broadleaves and grasses such as } \\
\text { morningglory, Florida pusley, and panicum }\end{array}$ \\
\hline MSMA & MSMA [99] & & $\begin{array}{l}\text { Grass and broadleaf species such as crabgrass, } \\
\text { Florida beggarweed, and Amaranthus spp. }\end{array}$ \\
\hline
\end{tabular}




\begin{tabular}{|c|c|c|c|}
\hline \multicolumn{4}{|l|}{ Herbicide } \\
\hline Common Name & Trade Name $^{a}$ & \multicolumn{2}{|c|}{ Application Timing Weed Species Controlled } \\
\hline \multicolumn{4}{|l|}{ LibertyLink Cotton } \\
\hline Glufosinate & Liberty ${ }^{\circ}$ & POST & $\begin{array}{l}\text { Broadleaf and grass species such as } \\
\text { Amaranthus spp., morningglory, and } \\
\text { goosegrass }\end{array}$ \\
\hline \multicolumn{4}{|c|}{ Roundup Ready Cotton } \\
\hline Glyphosate & Roundup WeatherMax & POST & $\begin{array}{l}\text { Grass and broadleaf species such as Florida } \\
\text { beggarweed, crabgrass, foxtail, groundcherry, } \\
\text { and velvetleaf }\end{array}$ \\
\hline \multicolumn{4}{|c|}{$\begin{array}{l}\text { aTrade names listed are representative of available herbicides. Inclusion of particular trade names does not suggest author } \\
\text { endorsement. }\end{array}$} \\
\hline \multicolumn{4}{|c|}{ bPRE, preemergence. } \\
\hline 'POST, postemerg & & & \\
\hline
\end{tabular}

Table 5. Herbicides for use in reduced-tillage cotton.

\section{Peanut}

Groundnut, or peanut (Arachis hypogaea L.), was planted on approximately 21 million ha between 2011 and 2012 wordwide with top production occurring in China, India, Indonesia, the United States, and some African countries such as Nigeria, Senegal, and Sudan [100]. Besides being a nutrient rich food source, the peanut is utilized for its oil in cooking and manufacturing as well as a livestock feed. In the United States, peanuts offer an exceptional rotational crop with cotton to replenish soil nitrogen. The benefits of peanuts to a cotton system, which have been shifting toward long-term, reduced-tillage practices, have necessitated the adoption of minimum tillage practices in peanut production as well.

The increased farming costs of conventional tillage systems have spurred producers to implement conservation-tillage to reduce expenses; however, peanut growers face unique difficulties when using these systems [101,102]. Particularly, concerns over peanut response to reduced-tillage due to peanut growth habits have required research in order to identify successful means of conservation-tillage integration into peanut production [102, 103].

Peanut yield variability under reduced-tillage compared to conventional tillage has been noted as one of the greatest concerns when adopting conservation-tillage practices [101,102]. Inconsistent yield response by peanut has been noted in previous studies investigating conservation-tillage. Research has reported yields of peanut to be reduced or equal to conventionally tilled peanut [101, 104]; other studies have shown reduced-tillage peanuts to produce equally or greater than conventional tillage peanuts [103,105]. Research efforts continue to recognize the contributing factors that affect peanut response to tillage systems. 
Weed management in conservation-tillage peanut is also a concern for producers. Weed control in peanut, regardless of tillage system, can be problematic due to the extended growing season and unique growth habits $[106,107]$. Generally, peanut production requires an incorporated residual as well as a POST herbicide to provide effective weed control under the slowclosing canopy of peanut [107]. Moreover, in-season cultivation for weed management cannot be implemented due to the potential to damage developing peanut pods $[106,108]$.

Weed control in reduced-tillage peanuts can be even more difficult than in conventional tillage due to the loss of weed control through seed burial and the inability to utilize preplant incorporated herbicides [109]. This results in increased dependence on post emergent herbicides which may or may not control the number of perennial weed species that may predominate in a reduced-tillage setting; the loss of effective weed management can reduce peanut productivity due to weed competition [102,107].

Utilization of cover crops in peanut systems may offer beneficial weed control while reducing the need for increased postemergent herbicide applications. Research has shown effective weed control with cover crops in strip-tillage peanut systems that use a dinitroaniline preemergent herbicide over cover crop residue [107]. Other effective herbicides used in conservation-tillage peanut systems are listed in Table 6.

\section{Herbicide interception}

Preemergent, residual herbicides must reach the soil surface to be effective. When spraying over cover crop residue, herbicide applications can be intercepted and absorbed prior to reaching the soil surface. Herbicides, such as acetochlor, chlorimuron, and oryzalin have been shown to be impeded by plant stubble $[113,114]$. While timely rainfall can move herbicides to the soil, some portion of herbicide can be retained in the residue.

Herbicide amounts intercepted by stubble can affect weed control achieved with the herbicide; efficacy can be reduced by cover crops either through physical interception preventing soil contact or through increased microbial activity in the residue speeding herbicide degradation [115]. Increases in soil organic matter from extended conservation-tillage practices may also increase herbicide adsorption within the soil [116]. Additionally, herbicide persistence and carryover risks may be increased when applied to residue [114]. Certain crops may be susceptible to herbicides at low doses that can persist in cover crop residue that would otherwise have dissipated in bare soil. However, little research has been done to determine the extent of persistence for most herbicides.

Methods to reduce herbicide interception are limited when using cover crops. Interception could potentially be managed, particularly in strip-till operations, through banded herbicide applications over the row allowing for in-row weed control while reducing herbicide inputs. Furthermore, a water-based, microencapsulated herbicide formulation, like Prowl $\mathrm{H}_{2} \mathrm{O}^{\circledR}$ (pendimethalin), may allow more herbicide to reach the soil after a rain event or irrigation. 


\begin{tabular}{|c|c|c|c|}
\hline \multicolumn{4}{|l|}{ Herbicide } \\
\hline Common Name & Trade Name ${ }^{a}$ & $\begin{array}{l}\text { Application } \\
\text { Timing }\end{array}$ & Weed Species Controlled \\
\hline Glyphosate & $\begin{array}{l}\text { Roundup WeatherMax } \\
\text { [25] }\end{array}$ & $\begin{array}{l}\text { Preplant } \\
\text { Burndown }\end{array}$ & Emerged weed species \\
\hline Paraquat & Gramoxone $[26]$ & & \\
\hline $2,4-D$ & Agri Star" 2,4-D [37] & & \\
\hline Diclosulam & Strongarm ${ }^{\circ}[110]$ & $\mathrm{PRE}^{\mathrm{b}}$ & $\begin{array}{l}\text { Broadleaf species such as eclipta (Eclipta prostrata) } \\
\text { and Amaranthus spp. }\end{array}$ \\
\hline Flumioxazin & Valor ${ }^{\circ}[39]$ & & $\begin{array}{l}\text { Broadleaf species such as horseweed (Conyza } \\
\text { canadensis) }\end{array}$ \\
\hline Pendimethalin & $\operatorname{Prowl}^{\circ}[40]$ & & $\begin{array}{l}\text { Grass and broadleaf species such as foxtail (Setaria } \\
\text { spp.) and Amaranthus spp. }\end{array}$ \\
\hline Acifluorfen & Ultra Blazer $[60]$ & $\mathrm{POST}^{\mathrm{C}}$ & $\begin{array}{l}\text { Broadleaf and grass species such as coffee senna } \\
\text { (Senna occidentalis) and velvetleaf (Abutilon } \\
\text { theophrasti) }\end{array}$ \\
\hline Bentazon & Basagran $^{*}[62]$ & & $\begin{array}{l}\text { Broadleaf species such as morningglory (Ipomoea } \\
\text { spp.) and velvetleaf }\end{array}$ \\
\hline Chlorimuron & Classic $^{*}[75]$ & & $\begin{array}{l}\text { Broadleaf weeds such as Florida beggarweed } \\
\text { (Desmodium tortuosum) and morningglory }\end{array}$ \\
\hline Clethodim & Select" [94] & & $\begin{array}{l}\text { Grass species such as panicum, foxtail, and } \\
\text { crabgrass (Digitaria spp.) }\end{array}$ \\
\hline Imazapic & Cadre $[111]$ & & $\begin{array}{l}\text { Broadleaf and grass species such as morningglory, } \\
\text { Amaranthus spp. and crabgrass }\end{array}$ \\
\hline Imazethapyr & Pursuit ${ }^{\circ}[78]$ & & $\begin{array}{l}\text { Broadleaf, grass, and sedge species such as Florida } \\
\text { pusley (Richardia scabra), crabgrass, and nutsedge } \\
\text { (Cyperus spp.) }\end{array}$ \\
\hline Paraquat & Gramoxone $^{\infty}$ & & Grass and broadleaf species \\
\hline Sethoxydim & Poast $^{*}[80]$ & & Grass species, foxtail and panicum \\
\hline 2,4-DB & Butyrac ${ }^{*}[112]$ & & $\begin{array}{l}\text { Broadleaf species such as velvetleaf and prickly sida } \\
\text { (Sida spinosa) }\end{array}$ \\
\hline
\end{tabular}

aTrade names listed are representative of available herbicides. Inclusion of particular trade names does not suggest author endorsement.

bPRE, preemergence.

'POST, postemergence.

Table 6. Herbicides for use in reduced-tillage peanut. 


\section{Conclusion}

The ever increasing demands on global agriculture dictate the use of intensive, high-yielding production practices. However, the inability to sustain these systems long-term necessitates the implementation of more energy-efficient, environmentally-sound practices that can still produce successful yields. Conservation agriculture practices seek to achieve these goals in order to ensure current and future agricultural production. While components of conservation agriculture, such as reduced-tillage and cover crops, are fundamental practices in these systems, herbicides are still valuable and necessary weed management tools within conservation systems. Integrating these management practices can be challenging and continue to warrant research to identify the most successful means of utilizes herbicides in conjunction with reduced-tillage and cover crops.

\section{Author details}

Andrew J. Price ${ }^{1^{*}}$ and Jessica A. Kelton ${ }^{2}$

*Address all correspondence to: Andrew.price@ars.usda.gov

1 United States Department of Agriculture, Agricultural Research Service, National Soil Dynamics Laboratory, Auburn, Alabama, USA

2 Auburn University, Auburn, Alabama, USA

\section{References}

[1] Reiter, M.S., D.W. Reeves, C.H. Burmester, H.A. Torbert. Cotton nitrogen management in a high-residue conservation system: Cover crop fertilization. Soil Science Society of America Journal, 2008; 72, 1321-1329, ISSN 1435-0661.

[2] Food and Agriculture Organization of the United Nations (FAO). FAOSTAT 2010. Available online at http://www.fao.org/ag/ca/index.html (accessed 13 August 2012).

[3] DeFelice, M.S., P.R. Carter, and S.B. Mitchell. Influence of tillage on corn and soybean yield in the US and Canada. Online. Crop Management. 2006. http://www.plantmanagementnetwork.org/pub/cm/research/2006/tillage/ (accessed 12 August 2012).

[4] Reeves, D.W. 1997. The role of soil organic matter in maintaining soil quality in continuous cropping systems. Soil and Tillage Research, 43, 131-167, ISSN 0167-1987.

[5] Truman, C.C., D.W. Reeves, J.N. Shaw, A.C. Motta, C.H. Burmester, R.L. Raper, and E.B. Schwab. Tillage impacts on soil property, runoff, and soil loss variations of a 
Rhodic Paleudult under simulated rainfall. Journal of Soil and Water Conservation, 2003; 58,258-267, ISSN 0022-4561.

[6] Swanton, C.J., K.J. Mahoney, K. Chandler, and R.H. Gulden. Integrated weed management: Knowledge-based weed management systems. Weed Science, 2008; 56, 168-172, ISSN 0043-1745.

[7] Norsworthy, J.K., M.S. Malik, P. Jha and M.B. Riley. Suppression of Digitaria sanguinalis and Amaranthus palmeri using autumn-sown glucosinolate-producing cover crops in organically grown bell pepper. Weed Research, 2007; 47, 425-432, ISSN 0043-1737.

[8] Treadwell, D.D, N.G. Creamer, J.R. Schultheis, and G.D. Hoyt. Cover crop management affects weeds and yield in organically managed sweetpotato systems. Weed Technology 2007; 21, 1039-1048, ISSN 0890-037X.

[9] Brennan, E.B. and R.F. Smith. Winter cover crop growth and weed suppression on the Central Coast of California. Weed Technology 2005; 19, 1017-1024, ISSN 0890-037X.

[10] Clark, A., editor. Managing Cover Crops Profitably. College Park, MD, USA: Sustainable Agricultural Research and Education (SARE); 2007.

[11] Price, A.J., J.A. Kelton. Weed control in conservation agriculture. In: Soloneski S. and M. Larramendy (ed.) Herbicides: Theory and Applications. Rijeka: InTech; 2010. p. 3-16.

[12] Gaston, L.A., D.J. Boquet, and M.A. Bosch. Pendimethalin wash-off from cover crop residues and degradation in a Loessial soil. Communications in Soil Science and Plant Analysis 2003; 34, 2515-2527, ISSN 0010-3624.

[13] Price, A.J., K.S. Balkcom, S.A. Culpepper, J.A. Kelton, R.L. Nichols, and H. Schomberg. Glyphosate-resistant Palmer amaranth: A threat to conservation tillage. Journal of Soil and Water Convervation 2011; 66(4), 265-275, ISSN 0022-4561.

[14] Mitchell, D.O. and M. Mielke. Wheat: The global market, policies, and priorities. In Aksoy M.A. and J.C. Beghin (eds.) Global Agricultural Trade and Developing Countries. Washington, DC, USA: World Bank; 2005. p. 195-214.

[15] Food and Agriculture Organization of the United Nations (FAO). Conservation agriculture 2011. Available online at http://www.fao.org/docrep/013/al977e/al977e00.pdf (accesssed 13 August 2012).

[16] Zhao, H., G. Gao, X. Yan, Q. Zhang, M. Hou, Y. Zhu, Z. Tian. Risk assessment of agricultural drought usning the CERES-Wheat model: a case study of Henan Plain, China. Climate Research 2011; 50, 247-256, ISSN 0936-577X.

[17] Bonfil, D.J., I. Mufradi, S. Klitman, and S. Asido. Wheat grain yield and soil profile water distribution in a no-till arid environment. Agronomy Journal 1999; 91, 368-373, ISSN 0002-1962. 
[18] De Vita, P., E. Di Paolo, G. Fecondo, N. Di Fonzo, and M. Pisante. No-tillage and conventional tillage effects on durum wheat yield, grain quality and soil moisture content in southern Italy. Soil and Tillage Research, 2007; 92, 69-78, ISSN 0167-1987.

[19] Gruber, S., C. Pekrun, J. Mohring, and W. Claupein. Long-term yield and weed response to conservation and stubble tillage in SW Germany. Soil and Tillage Research, 2012; 121, 49-56, ISSN 0167-1987.

[20] Wilson, H.P., M.P. Masgianica, T.E. Hines, and R.F. Walden. Influence of tillage and herbicides on weed control in a wheat (Triticum aestivum)- soybean (Glycine max) rotation. Weed Science, 1986; 34, 590-594, ISSN 0043-1745.

[21] Guy, S.O. and R.M. Gareau. Crop rotation, residue durability, and nitrogen fertilizer effects on winter wheat production. Journal of Production Agriculture, 1998; 11, 457-461, ISSN 0890-8524.

[22] Dao, T.H. Crop residues and management of annual grass weeds in continuous notill wheat (Triticum aestivum). Weed Science, 1987; 35, 395-400, ISSN 0043-1745.

[23] FMC Corporation. 2012. Aim ${ }^{\circledR}$ Herbicide Label. Philadelphia, PA, USA: FMC Corporation Agricultural Products Group. 15 p.

[24] Bayer CropScience. 2011. Liberty ${ }^{\circledR}$ Herbicide Label. Research Triangle Park, NC, USA: Bayer CropScience LP. 20 p.

[25] Monsanto Company. 2009. Roundup WeatherMax ${ }^{\circledR}$ Herbicide Label. St. Louis, MO, USA: Monsanto Company. 54 p.

[26] Syngenta Crop Protection. 2011. Gramoxone ${ }^{\circledR}$ Herbicide Label. Greensboro, NC, USA: Syngenta Crop Protection, LLC. 55 p.

[27] E. I. du Pont de Nemours and Company. 2009. DuPont ${ }^{\mathrm{TM}}$ Finesse $^{\circledR}$ Herbicide Label. Wilmington, DE, USA: E.I. du Pont de Nemours and Company, Inc. 12 p.

[28] Bayer CropScience. 2011. Huskie ${ }^{\mathrm{TM}}$ Herbicide Label. Research Triangle Park, NC, USA: Bayer CropScience LP. 24 p.

[29] E. I. du Pont de Nemours and Company. 2010. DuPont ${ }^{\mathrm{TM}}$ Harmony ${ }^{\circledR}$ Extra Herbicide Label. Wilmington, DE, USA: E.I. du Pont de Nemours and Company, Inc. 13 p.

[30] BASF Corporation. 2011. Beyond ${ }^{\circledR}$ Herbicide Label. Research Triangle Park, NC, USA: BASF Corporation. $23 \mathrm{p}$.

[31] Yenish, J.P., A.D. Worsham, and A.C. York. Cover crops for herbicide replacement in no-tillage corn (Zea mays). Weed Technology 1996; 10, 815-821, ISSN 0890-037X.

[32] Clark, A.J., A.M. Decker, and J.J. Meisinger. Seeding rate and kill date effects on hairy vetch-cereal rye cover crop mixtures for corn production. Agronomy Journal, 1994; 86, 1065-1070, ISSN 0002-1962. 
[33] Fisk, J.W., O.B. Hesterman, A. Shrestha, J.J. Kells, R.R. Harwood, H.M. Squire, and C.C. Sheaffer. Weed suppression by annual legume cover crops in no-tillage corn. Agronomy Journal, 2001; 93, 319-325, ISSN 0002-1962.

[34] Utomo, M., W.W. Frye, and R.L. Blevins. Sustaining soil nitrogen for corn using hairy vetch cover crop. Agronomy Journal, 1990; 82, 979-983, ISSN 0002-1962.

[35] Wagger, M.G. Cover crop management and nitrogen rate in relation to growth and yield of no-till corn. Agronomy Journal, 1989; 81, 533-538, ISSN 0002-1962.

[36] Decker, A.M., A.J. Clark, J.J. Meisinger, F. Ronald Mulford, and M.S. McIntosh. Legume cover crop contributions to no-tillage corn production. Agronomy Journal, 1994; 86, 126-135, ISSN 0002-1962.

[37] Albaugh. 2012. Agri Star ${ }^{\circledR}$ 2,4-D Amine Herbicide Label. Ankeny, IA, USA: Albaugh, Inc. $36 \mathrm{p}$.

[38] Syngenta Crop Protection. 2009. Aatrex ${ }^{\circledR}$ Herbicide Label. Greensboro, NC, USA: Syngenta Crop Protection, LLC. 24 p.

[39] Valent U.S.A. 2010. Valor ${ }^{\circledR}$ Herbicide Label. Walnut Creek, CA, USA: Valent U.S.A. Corporation. $27 \mathrm{p}$.

[40] BASF Corporation. 2008. Prow ${ }^{\circledR}$ Herbicide Label. Research Triangle Park, NC, USA: BASF Corporation. $24 \mathrm{p}$.

[41] Syngenta Crop Protection. 2011. Dual Magnum ${ }^{\circledR}$ Herbicide Label. Greensboro, NC, USA: Syngenta Crop Protection, LLC. 54 p.

[42] Bayer CropScience. 2005. Buctril ${ }^{\circledR}$ Herbicide Label. Research Triangle Park, NC, USA: Bayer CropScience LP. 36 p.

[43] Arysta LifeScience. 2004. Banvel ${ }^{\circledR}$ Herbicide Label. Cary, NC, USA: Arysta LifeScience North America, LLC. 27 p.

[44] Syngenta Crop Protection. 2012. Callisto ${ }^{\circledR}$ Herbicide Label. Greensboro, NC, USA: Syngenta Crop Protection, LLC. 32 p.

[45] Bayer CropScience. 2010. Laudis ${ }^{\circledR}$ Herbicide Label. Research Triangle Park, NC, USA: Bayer CropScience LP. 19 p.

[46] Syngenta Crop Protection. 2011. Evik ${ }^{\circledR}$ Herbicide Label. Greensboro, NC, USA: Syngenta Crop Protection, LLC. 8 p.

[47] Tessenderlo. 2010. Lorox ${ }^{\circledR}$ Herbicide Label. Phoenix, AZ, USA: Tessenderlo Kerley, Inc. $14 \mathrm{p}$.

[48] BASF Corporation. 2008. Lightning ${ }^{\circledR}$ Herbicide Label. Research Triangle Park, NC, USA: BASF Corporation. $10 \mathrm{p}$. 
[49] Syngenta Crop Protection. 2009. Expert ${ }^{\circledR}$ Herbicide Label. Greensboro, NC, USA: Syngenta Crop Protection, LLC. 31 p.

[50] Fairhurst, T.H. and A. Dobermann. Rice in the global food supply. Better Crops International, 2002; 16, 3-6. http://www.ipni.net/ppiweb/bcropint.nsf/\$webindex/ 0E477FFC43BD62 DA85256BDC00722F62/\$file/BCI-RICEp03.pdf. (accessed 31 August 2012).

[51] Farooq, M., K.H.M. Siddique, H. Rehman, T. Aziz, D. Lee, and A. Wahid. Rice direct seeding: Experiences, challenges and opportunities. Soil and Tillage Research, 2011; 111, 87-98, ISSN 0167-1987.

[52] Mishra, J.S. and V.P. Singh. Tillage and weed control effects on productivity of a dry seeded rice-wheat system on a Vertisol in Central India. Soil and Tillage Research, 2012; 123, 11-20, ISSN 0167-1987.

[53] Chauhan, B.S. and D.E. Johnson. Influence of tillage systems on weed seedling emergence pattern in rainfed rice. Soil and Tillage Research, 2009; 106, 15-21, ISSN 0167-1987.

[54] Rao, A.N., D.E. Johnson, B. Sivaprasad, J.K. Ladha. and A.M. Mortimer. Weed management in direct-seeded rice. Advances in Agronomy, 2007; 93, 153-255, ISSN 0065-2113.

[55] Becker, M. and D.E. Johnson. Legumes as dry season fallow in upland rice-based systems of West Africa. Biology and Fertility of Soils, 1998; 27, 358-367, ISSN 0178-2762.

[56] FMC Corporation. 2011. Command ${ }^{\circledR}$ Herbicide Label. Philadelphia, PA, USA: FMC Corporation Agricultural Products Group. 19 p.

[57] Gowan Company. 2007. Permit ${ }^{\circledR}$ Herbicide Label. Yuma, AZ, USA: Gowan Company. $18 \mathrm{p}$.

[58] BASF Corporation. 2010. Facet ${ }^{\circledR}$ Herbicide Label. Research Triangle Park, NC, USA: BASF Corporation. 9 p.

[59] Valent U.S.A. 2001. Bolero ${ }^{\circledR}$ Herbicide Label. Walnut Creek, CA, USA: Valent U.S.A. Corporation. 4 p.

[60] United Phosphorus. 2009. Ultra Blazer ${ }^{\circledR}$ Herbicide Label. King of Prussia, PA, USA: United Phosphorus, Inc. $10 \mathrm{p}$.

[61] United Phosphorus. 2010. Londax ${ }^{\circledR}$ Herbicide Label. King of Prussia, PA, USA: United Phosphorus, Inc. 9 p.

[62] Arysta LifeScience. 2005. Basagran ${ }^{\circledR}$ Herbicide Label. Cary, NC, USA: Arysta LifeScience North America, LLC. 12 p.

[63] United Phosphorus. 2010. Stam ${ }^{\circledR}$ Herbicide Label. King of Prussia, PA, USA: United Phosphorus, Inc. 7 p. 
[64] Dow AgroSciences. 2011. Clincher ${ }^{\circledR}$ Herbicide Label. Indianapolis, IN, USA: Dow AgroSciences LLC. 4 p.

[65] BASF Corporation. 2011. Newpath ${ }^{\circledR}$ Herbicide Label. Research Triangle Park, NC, USA: BASF Corporation. $12 \mathrm{p}$.

[66] BASF Corporation. 2011. Clearpath ${ }^{\circledR}$ Herbicide Label. Research Triangle Park, NC, USA: BASF Corporation. $10 \mathrm{p}$.

[67] Ebel, R. Soil management and conservation. In: Osteen, C., J. Gottlieb, and U. Vasavada (eds.) Agricultural Resources and Environmental Indicators, 2012. EIB-98, United States Department of Agriculture, Economic Research Service, August 2012. p 33-36. Available from http://www.ers.usda.gov/Publications/eib- economic-information-bulletin/eib98.aspx (accessed 5 September 2012).

[68] Campbell, R.B., R.E. Sojka, and D.L. Karlen. Conservation tillage for soybean in the U.S. Southeastern Coastal Plain. Soil and Tillage Research, 1984; 4, 531-541, ISSN 0167-1987.

[69] Robinson, E.L., G.W. Langdale, and J.A. Stuedemann. Effect of three weed control regimes on no-till and tilled soybeans (Glycine max). Weed Science, 1984; 32, 17-19, ISSN 0043-1745.

[70] Price, A.J., D.W. Reeves, and M.G. Patterson. Evaluation of weed control provided by three winter cereals in conservation-tillage soybean. Renewable Agriculture and Food Systems, 2005; 21, 159-164, ISSN 1742-1705.

[71] Liebl, R., F.W. Simmons, L.M. Wax, and E.W. Stoller. Effect of rye (Secale cereale) mulch on weed control and soil moisture in soybean (Glycine max). Weed Technology, 1992; 6, 838-846, ISSN 0890-037X.

[72] BASF Corporation. 2008. Outlook ${ }^{\circledR}$ Herbicide Label. Research Triangle Park, NC, USA: BASF Corporation. $17 \mathrm{p}$.

[73] BASF Corporation. 2009. Scepter ${ }^{\circledR}$ Herbicide Label. Research Triangle Park, NC, USA: BASF Corporation. $15 \mathrm{p}$.

[74] Loveland Products. 2008. Metribuzin Herbicide Label. Greeley, CO, USA: Loveland Products, Inc. 26 p.

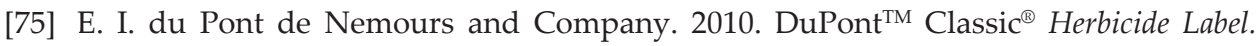
Wilmington, DE, USA: E.I. du Pont de Nemours and Company, Inc. 15 p.

[76] Dow AgroSciences. 2011. FirstRate ${ }^{\circledR}$ Herbicide Label. Indianapolis, IN, USA: Dow AgroSciences LLC. 6 p.

[77] Syngenta Crop Protection. 2011. Fusilade ${ }^{\circledR}$ Herbicide Label. Greensboro, NC, USA: Syngenta Crop Protection, LLC. 39 p. 
[78] BASF Corporation. 2011. Pursuit ${ }^{\circledR}$ Herbicide Label. Research Triangle Park, NC, USA: BASF Corporation. $27 \mathrm{p}$.

[79] Valent U.S.A. 2007. Cobra ${ }^{\circledR}$ Herbicide Label. Walnut Creek, CA, USA: Valent U.S.A. Corporation. 29 p.

[80] BASF Corporation. 2010. Poast ${ }^{\circledR}$ Herbicide Label. Research Triangle Park, NC, USA: BASF Corporation. $24 \mathrm{p}$.

[81] Syngenta Crop Protection. 2009. Flexstar ${ }^{\circledR}$ Herbicide Label. Greensboro, NC, USA: Syngenta Crop Protection, LLC. 26 p.

[82] National Cotton Council of America. Production Ranking 2012. http:// www.cotton.org/econ/cropinfo/cropdata/rankings.cfm (accessed 5 September 2012).

[83] Carpenter, J. and L. Gianessi. Herbicide tolerant soybeans: Why growers are adopting Roundup Ready varieties. AgBioForum, 1999; 2, 65-72, ISSN 1522-936X.

[84] Schwab, E.B., D.W. Reeves, C.H. Burmester, and R.L. Raper. Conservation tillage systems for cotton in the Tennessee Valley. Soil Science Society of America Journal, 2002; 66, 569-577, ISSN 1435-0661.

[85] Nyakatawa, E.Z., K.C. Reddy, and D.A. Mays. Tillage, cover cropping, and poultry litter effects on cotton: II. Growth and yield parameters. Agronomy Journal, 2000; 92, 1000-1007, ISSN 1435-0645.

[86] Keeling, W., E. Segarra, and J.R. Abernathy. Evaluation of conservation tillage cropping systems for cotton on the Texas Southern High Plains. Journal of Production Agriculture, 1989; 2, 269-273, ISSN 0890-8524.

[87] Bauer, P.J. and D.W. Reeves. A comparison of winter cereal species and planting dates as residue cover for cotton growth with conservation tillage. Crop Science, 1999; 39, 1824-1830, ISSN 0002-1962.

[88] Reeves, D.W., A.J. Price, and M.G. Patterson. Evaluation of three winter cereals for weed control in conservation-tillage nontransgenic cotton. Weed Technology, 2005; 19, 731-736, ISSN 0890-037X.

[89] Johnson, M.D., D.L. Wyse, and W.E. Lueschen. The influence of herbicide formulation on weed control in four tillage systems. Weed Science, 1989; 37, 239-149, ISSN 0043-1745.

[90] Lindwall, C.W. Crop management in conservation tillage systems. In P. Unger (ed.) Managing Agricultural Residues. Boca Raton, FL, USA: Lewis Publishing, 1994. p. 185-210.

[91] Westerman, P.A., M. Liebman, F.D. Menalled, A.H. Heggenstaller, R.G. Hartzler, and P.M. Dixon. Are many little hammers effective? Velvetleaf (Abutilon theophrasti) population dynamics in two- and four-year crop rotation systems. Weed Science, 2005; 53, 382-392, ISSN 0043-1745. 
[92] Makhteshim Agan. 2009. Cotoran ${ }^{\circledast}$ Herbicide Label. Raleigh, NC, USA: Makhteshim Agan of North America, Inc. 6 p.

[93] Syngenta Crop Protection. 2011. Caparol ${ }^{\circledR}$ Herbicide Label. Greensboro, NC, USA: Syngenta Crop Protection, LLC. 21 p.

[94] Valent U.S.A. 2007. Select ${ }^{\circledR}$ Herbicide Label. Walnut Creek, CA, USA: Valent U.S.A. Corporation. $30 \mathrm{p}$.

[95] E. I. du Pont de Nemours and Company. 2010. DuPont ${ }^{\mathrm{TM}}$ Assure $^{\circledR}$ Herbicide Label. Wilmington, DE, USA: E.I. du Pont de Nemours and Company, Inc. 13 p.

[96] Syngenta Crop Protection. 2011. Envoke ${ }^{\circledR}$ Herbicide Label. Greensboro, NC, USA: Syngenta Crop Protection, LLC. 43 p.

[97] E. I. du Pont de Nemours and Company. 2011. DuPont ${ }^{\mathrm{TM}}$ Direx ${ }^{\circledR}$ Extra Herbicide Label. Wilmington, DE, USA: E.I. du Pont de Nemours and Company, Inc. 21 p.

[98] Tessenderlo. 2010. Linex ${ }^{\circledR}$ Herbicide Label. Phoenix, AZ, USA: Tessenderlo Kerley, Inc. $14 \mathrm{p}$.

[99] Drexel Chemical Company. 2009. MSMA Herbicide Label. Memphis, TN, USA: Drexel Chemical Company. 4 p.

[100] United States Department of Agriculture Foreign Agricultural Service (USDA-FAS). Peanut area, yield, and production. http://www.fas.usda.gov/psdonline/psdreport.aspx? hidReportRetrievalName=BVS\&hidReportRetrievalID=918\&hidReportRetrievalTemplateID=1\#ancor (accessed 5 September 2012).

[101] Jordan, D.L., J.S. Barnes, C.R. Bogle, G.C. Naderman, G.T. Roberson, and P.D. Johnson. Peanut response to tillage and fertilization. Agronomy Journal, 2001; 95, 1125-1130, ISSN 0002-1962.

[102] Tubbs, R.S. and R.N. Gallaher. Conservation tillage and herbicide management for two peanut cultivars. Agronomy Journal, 2005; 97, 500-504, ISSN 0002-1962.

[103] Johnson, W.C. III, T.B. Brenneman, S.H. Baker, A.W. Johnson, D.R. Sumner, and B.G. Mullinix, Jr. Tillage and pest management considerations in a peanut-cotton rotation in the Southeastern coastal plain. Agronomy Journal, 2001; 93, 570-576, ISSN 0002-1962.

[104] Brandenberg, R.L., D.A. Herbert, Jr., G.A. Sullivan, G.C. Naderman, and S.F. Wright. The impact of tillage practices on thrips injury of peanut in North Carolina and Virginia. Peanut Science, 1998; 25, 27-31, ISSN 0095-3679.

[105] Marois, J.J. and D.L. Wright. Effect of tillage system, phorate, and cultivar on tomato spotted wilt of peanut. Agronomy Journal, 2003; 95, 386-389, ISSN 0002-1962.

[106] Wilcut, J.W., A.C. York, W.J. Grichar, and G.R. Wehtje. The biology and management of weeds in peanut (Arachis hypogaea). In H.E. Pattee and H.T. Stalker (eds.) Advan- 
ces in Peanut Science. Stillwater, OK, USA: American Peanut Research Educational Society, 1995. p. 207-244.

[107] Grichar, W.J., B.A. Besler, R.G. Lemon, and K.D. Brewer. Weed management and net returns using soil-applied and postemergence herbicide programs in peanut (Arachis hypogaea L.). Peanut Science, 2005; 32, 25-31, ISSN 0095-3679.

[108] Rao, V.R. and U.R. Murty. Botany-morphology and anatomy. In J. Smartt (ed.) The Groundnut Crop: A Scientific Basis for Improvement. London: Chapman \& Hall, 1994. p. 43-95.

[109] Price, A.J. and J.W. Wilcut. Weed management with diclosulam in strip-tillage peanut (Arachis hypogaea). Weed Technology, 2002; 16, 29-36, ISSN 0890-037X.

[110] Dow AgroSciences. 2010. Strongarm ${ }^{\circledR}$ Herbicide Label. Indianapolis, IN, USA: Dow AgroSciences LLC. 5 p.

[111] BASF Corporation. 2012. Cadre ${ }^{\circledR}$ Herbicide Label. Research Triangle Park, NC, USA: BASF Corporation. 9 p.

[112] Albaugh. 2010. Agri Star ${ }^{\circledR}$ Butyrac $^{\circledR}$ Herbicide Label. Ankeny, IA, USA: Albaugh, Inc. 9 p.

[113] Banks, P.A. and E.L. Robinson. Soil reception and activity of acetochlor, alachlor, and metolachlor as affected by wheat (Triticum aestivum) straw and irrigation. Weed Science, 1986; 34, 607-611, ISSN 0043+1745.

[114] Schmitz, G.L., W.W. Witt, and T.C. Mueller. The effect of wheat (Triticum aestivum) straw levels on chlorimuron, imazaquin, and imazethapyr dissipation and interception. Weed Technology, 2001; 15, 129-136, ISSN 0890-037X.

[115] Reddy, K.N., M.A. Locke, and L.A. Gaston. Tillage and cover crop effects on cyanazine adsorption and desorption kinetics. Soil Science, 1997; 162, 501-509, ISSN 0038-075X.

[116] Locke, M.A., K.N. Reddy, and R.M. Zablotowicz. Weed management in conservation crop production systems. Weed Biology and Management, 2002; 2, 123-132, ISSN $1445-6664$. 